\title{
Diversity of Endophytic and Epiphytic Bacteria From Sugarcane in Khuzestan, Iran
}

\author{
Hossein Moazzen Rezamahalleh ${ }^{1}$ \\ https://orcid.org/0000-0002-6510-0198 \\ Gholam Khodakaramian ${ }^{\star}$ \\ https://orcid.org/0000-0002-9500-5888 \\ Nader Hassanzadeh ${ }^{3}$ \\ https://orcid.org/0000-0003-4168-1001 \\ ${ }^{1 \& 3}$ Islamic Azad University, Science And Research Branch. Faculty Of Agricultural Sciences And Food \\ Industries, Department Of Plant Protection. Tehran, Iran. \\ ${ }^{2}$ Bu-Ali Sina University, College Of Agriculture, Department Of Plant Protection, Hamedan, Iran.
}

Received: 2018.09.25; Accepted: 2019.07.08.

*Correspondence: khodakaramian@yahoo.com; Tel.: +98(813)4424091 (G.K.)

\section{HIGHLIGHTS}

- The Endophytic and Epiphytic Bacterial Flora of Sugarcane Was Studied in Khuzestan.

- Both Leaves and Sheaths Showed a High Diversity of Endophytic and Epiphytic Bacteria

- The Diversity of Bacteria in the Leaves Were Significantly More Than That of Sheaths.

Abstract: Diverse microorganisms are living as endophytes in plant tissues and as epiphytes on plant surfaces in nature. Commercial formulations of bacteria antagonist to plant pathogenic microbes and ice nucleation active bacteria have been utilized as an environmentally safe method to manage plant disease and to prevent frost damage respectively. Bacteria were isolated from the leaf and sheath of sugarcane (CP69-1026 CP57-614, CP48-103, CP73-21, and CP70-1143 cultivars) verities grown in the field in Khuzestan province, Iran. Bacteria were found in both sheaths and leaves of sugarcane plants which they were significantly higher in density in leaves and which most were endophytic. The bacterial strains were 10 groups on the basis of the biochemical characteristic, which their 16S rRNA encoding gene from representatives were amplified and subjected to sequencing. Results of sequences analyze using blast software from the $\mathrm{NCBI}$ website and phylogenetic analysis showed that the representative strains belonged to a wide variety of phylogenetic groups. These results indicated that they were closely related to Burkholderia and Ralstonia from $\beta$-Proteobacteria, Mesorhizobium, Ochrobactrum, Sphingomonas from $\alpha$-Proteobacteria, Microbacterium, 
Curtobacterium and Leifsonia from Actinobacteria and Xanthomonas from $y$-Proteobacteria. This is the first report of the presence of endophytic and epiphytic bacteria from sugarcane in Khuzestan, Iran.

Keywords: $16 S$ rRNA; Diversity; Endophytic bacteria; Sugarcane; Khuzestan.

\section{INTRODUCTION}

Sugarcane (Saccharum officinarum) is a member of the family Poaceae which is best characterized by its high sucrose amount. It is a major world industrial crop, which is used in the manufacturing of important chemicals and industrial products, including MDF, pulp and medical alcohol from molasses, brown sugar, flavored sugar, and powdery sugar. Currently, it represents one of the most important sugar sources, being cultivated in more than 50 countries. The economic significance of the sugar cane, known as the magic plant, is not overlooked by anyone, and as a strategic product, it has a special place among the agricultural production in Iran. Since a long time ago, Khuzestan Province has been one of the important centers of production of sugarcane. In some cases, production of 220 tons cane per hectare has been seen in this province. So, the cultivation of sugarcane in this province is considered a relative preference.

The aerial parts of plants including leaves, stems, buds, flowers, and fruits provide habitat for microorganisms termed the phyllosphere. Microbes can be found both as epiphytes on the plant surface and as endophytes within plant tissues [1-6]. One might expect the importance of particular abiotic factors to vary, depending upon the location of the microbial community within the plant, and this may have repercussions for the structure of microbial communities. For example, the microbial community residing in the phyllosphere (the aerial parts of plants) is faced with a nutrient poor and variable environment that is characterized by fluctuating temperature, humidity and UV radiation (Bacteria are considered to be the dominant microbial inhabitants of the phyllosphere [3, 7]. Phyllosphere bacteria can promote plant growth and both suppress and stimulate the colonization and infection of tissues by plant pathogens [3, 8]. A phyllospheric study can also be helpful to find out some relation between parasite plants and their hosts [9]. As well as, prokaryotes are directly linked to the action of plants, and various endophytes were found in sugarcane. Therefore, clarification of the diversity and function of the endophytic and epiphytic may more effectively help to clarify their roles in their hosts. However, the microbial diversity in aerial parts of sugarcane in Khuzestan is yet poorly characterized. Our main objective was to describe and compare epiphytic and endophytic bacterial communities associated with the sheath and leaves of sugarcane in Khuzestan.

\section{MATERIALS AND METHODS}

\section{Plant samples, isolation of bacteria and culture conditions}

During the winter and summer of 2017, plant samples were collected at several stages from sugar cane fields located in the north and south of Khuzestan. The cultivated of sugarcane verities which were subjected to sampling were CP69-1026 CP57-614, CP48-103, CP73-21, and CP70-1143 cultivars. All Samples were transferred to the laboratory of pathology located at the Sugar Research and Training Institute of Khuzestan. For isolation of epiphytic bacteria, sugarcane leaves from the stems and sheath were detached and placed in $100 \mathrm{ml}$ sterilized distilled water containing $1 \mathrm{~g}$ gelatin and placed on a 120rpm shaker for 45 minutes. A loopful of the resulting suspension was streaked onto YPGA (Yeast extract: $7 \mathrm{~g} / \mathrm{l}^{-1}$, Peptone: $7 \mathrm{~g} / \mathrm{l}^{-1}$, Glucose: $7 \mathrm{~g} / \mathrm{l}^{-1}$, Agar: $15 \mathrm{~g} / \mathrm{l}^{-1}$ ) medium [10]. The plates were incubated at $25-27^{\circ} \mathrm{C}$ for $48-$ $72 \mathrm{~h}$. To isolate the endophytic bacteria, the sugar cane leaves are separated from the stems, 
then the leaves were washed with sterile distilled water and their surface disinfected by washing with $70 \%$ ethanol. The stems were treated in the same way. Afterward, the leaves and stems disinfected, macerated in $100 \mathrm{ml}$ sterilized distilled water containing $1 \mathrm{~g}$ gelatin and $1 \mathrm{~g} \mathrm{NaCl}$. The suspensions were placed on a $120 \mathrm{rpm}$ shake for $30 \mathrm{~min}$ and appropriate cultures were made. All bacterial isolates were purified on YDC (Yeast extract: $10 \mathrm{~g} / \mathrm{l}^{-1}$, Dextrose (glucose): $20 \mathrm{~g} / \mathrm{l}^{-1}$, Calcium carbonate: $20 \mathrm{~g} / \mathrm{l}^{-1}$, Agar: $15 \mathrm{~g} / \mathrm{l}^{-1}$ ) medium. The appropriate amount of the bacterial strains re-suspended in sterilized distilled water and stored at $4{ }^{\circ} \mathrm{C}$ for further investigation. For the long-term storage, the bacterial strains were suspended in $15 \%$ glycerol and kept at $-70^{\circ} \mathrm{C}$.

\section{Biochemical characterization of the bacterial strains}

For the determination of the phenotypic features of the bacterial strains standard bacteriological methods were employed [10]. Phenotypic features include Gram reaction, oxidase and catalase activity, aerobic/anaerobic growth $(\mathrm{O} / \mathrm{F})$, levan formation, fluorescent pigment on King's B medium, growth at $40^{\circ} \mathrm{C}$, proteolytic and pectolytic activity, and colony characteristics on yeast extract-dextrose-calcium carbonate (YDC) agar medium were determined [11]. The biochemical tests were repeated twice.

\section{Amplification of $16 S$ rRNA encoding genes and its sequencing}

DNA was extracted from the representative bacterial strains using the boiling cells method [10]. Genomic DNA was used as a template for the amplification of $16 S$ rRNA encoding genes using polymerase chain reaction (PCR) with the universal primers fD1 (5'AGAGTTTGATCCTGGCTCAG-3') and rP2 (5'- ACGGCTACCTTGTTACGACTT-3'). The reaction was performed to amplification of a fragment of approximately $1500 \mathrm{bp}$ of the $16 S$ rRNA encoding gene. The Universal PCR Kit, Gene PAK ${ }^{\circledR}$ PCR MasterMix Core (ISOGENE Laboratory, Moscow, Russia), was used and the experiments were carried out based on the manufacturer's recommendations. Each reaction test tube contains a $25 \mu \mathrm{l}$ PCR mixture which a 50 -ng total DNA and $1 \mu \mathrm{l}$ of each primer $\left(10 \mathrm{pmol} \times \mu \mathrm{l}^{-1}\right)$ were added. The PCR program was as an initial denaturation at $95^{\circ} \mathrm{C}$ for $5 \mathrm{~min}$, followed by 35 cycles of denaturation at $95^{\circ} \mathrm{C}$ for $30 \mathrm{~s}$, annealing at $63^{\circ} \mathrm{C}$ for $45 \mathrm{~s}$, extension at $72^{\circ} \mathrm{C}$ for $30 \mathrm{~s}$ and a final extension at $72^{\circ} \mathrm{C}$ for $10 \mathrm{~min}$. The amplified products were separated through electrophoresis using agarose gel (1.2\%) under electric conditions of $100 \mathrm{~mA}$ in TBE buffer, stained with CinnaGen DNA safe Stain (Cat. No. F.P5082, CinnaGen Co., Tehran, Iran) and visualized under UV light.

\section{PCR product sequencing and phylogenetic analysis}

PCR products were subjected to sequencing (Bioneer Corporation: http://www. Bioneer.com) and the resulting sequences were aligned by using the multiple sequence alignment program, CLUSTAL W [12]. Phylogenetic analysis was performed using MEGA 6.06 software [13]. All sequences were deposited in GenBank and assigned an accession number. Phylogenetic analysis was performed using the Maximum Likelihood method [13]. The phylogenetic trees were constructed with bootstrapping (1000 replications) using MEGA 6.06 software [14]. 


\section{RESULTS}

\section{Isolation and identification of the endophytic and epiphytic bacteria}

A total of 390 strains of bacterial strains were isolated from sugarcane and stem leaves, all stored at $15 \%$ glycerol at $-70^{\circ} \mathrm{C}$. Of these 390 strains, 67 strains were selected as the representative based on the results of the biochemical tests mentioned above. Except for the species related to genus Xanthomonas, the rest of the Gram-negative genera have a positive oxidase and all the Gram-positive showed a negative reaction for oxidase. Results of phenotypic determination indicated that four Gram-positive bacterial species in three genera and fourteen Gram-negative bacterial species in six genera present in sugarcane leaves and stems suggesting adaptation and co-evolution of diverse bacteria with their host sugarcane plants. We found that epiphytic and endophytic bacterial populations in the leave were more diverse than the stem. The density of the endophytic bacterial population was higher than the epiphytic samples. The sugarcane leaves contain a more diverse bacterial genus than stems.

\section{Sequence analysis}

The nucleotide sequences of $16 S$ rRNA encoding genes of 67 representatives were determined and aligned with those of reference strains in GenBank (Figure 1). Except for isolate SC112, other isolates showed high similarity $(\geq 97 \%)$ with their closest related species. Phylogenetic analysis of $16 S$ rRNA sequences showed that all isolates obtained in this study clustered with the type strain of each species. Most of the strains belonged to the $\beta$ proteobacteria. Results of this study allowed us to cluster the sugarcane bacteria into 4 distinct groups: Group I was composed of members of the Burkholderiaceae family. This group contains 45 strains, which was the most populated group. The strains of this group were clustered with Burkholderia and Ralstonia. Group II consists of bacteria from the $\alpha$-Proteobacteria group include the genus, Ochrobactrum and Sphingomonas. Group III had three representatives of the Actinobacteria (a group of Gram-positive bacteria with high $\mathrm{G}+\mathrm{C}$ content) which include Leifsonia, Curtobacterium, and Microbacterium. Group IV had a single representative of the $y$ Proteobacteria phylum (SC166) related to Xanthomonas. This is the only genus of Gram negative bacteria that have negative oxidase (Table 1). 
Table 1. The16SrRNA sequence analyses of the endophytic and epiphytic bacteria isolated from sugarcane plants in Khuzestan province, Iran

\begin{tabular}{|c|c|c|c|c|c|c|}
\hline \multirow[t]{2}{*}{ Groups } & \multicolumn{2}{|l|}{ Characteristics of isolates } & \multirow[t]{2}{*}{$\begin{array}{l}\text { Max } \\
\text { identity } \\
\text { (\%) }\end{array}$} & \multirow[t]{2}{*}{$\begin{array}{l}\text { Accession } \\
\text { no. }\end{array}$} & \multirow[t]{2}{*}{$\begin{array}{l}\text { Separated } \\
\text { source }\end{array}$} & \multirow[t]{2}{*}{$\begin{array}{l}\text { Type of } \\
\text { bacteria }\end{array}$} \\
\hline & Hit in NCBI database & Strain & & & & \\
\hline Group I & Burkholderia gladioli & SC101 & 99 & MH254946 & Leaf & Endo $^{1}$ \\
\hline$\beta$-proteobacteria & Burkholderia gladioli & SC102 & 99 & MH256558 & Leaf & Endo \\
\hline \multirow[t]{31}{*}{ Burkholderiaceae family } & Burkholderia gladioli & SC103 & 99 & MH256493 & Leaf & Endo \\
\hline & Burkholderia gladioli & SC104 & 99 & MH256559 & sheath & Endo \\
\hline & Burkholderia gladioli & SC105 & 99 & MH256554 & Leaf & $E p i^{2}$ \\
\hline & Burkholderia gladioli & SC106 & 99 & MH256560 & Leaf & Epi \\
\hline & Burkholderia gladioli & SC107 & 99 & MH256555 & Leaf & Epi \\
\hline & Burkholderia gladioli & SC108 & 99 & MH256494 & Leaf & Epi \\
\hline & Burkholderia gladioli & SC109 & 99 & MH256495 & Leaf & Epi \\
\hline & Burkholderia gladioli & SC110 & 99 & MH256496 & sheath & Epi \\
\hline & Burkholderia fungorum & SC111 & 99 & MH256497 & Leaf & Endo \\
\hline & Burkholderia fungorum & SC112 & 85 & MH256498 & Leaf & Endo \\
\hline & Burkholderia fungorum & SC113 & 100 & MH256499 & Leaf & Endo \\
\hline & Burkholderia fungorum & SC114 & 100 & MH256500 & Leaf & Endo \\
\hline & Burkholderia fungorum & SC115 & 99 & MH256501 & Leaf & Endo \\
\hline & Burkholderia fungorum & SC116 & 99 & MH256502 & Leaf & Endo \\
\hline & Burkholderia fungorum & SC117 & 99 & MH256503 & Leaf & Endo \\
\hline & Burkholderia fungorum & SC118 & 100 & MH256504 & Leaf & Endo \\
\hline & Burkholderia fungorum & SC119 & 99 & MH256505 & Leaf & Epi \\
\hline & Burkholderia fungorum & SC120 & 99 & MH256506 & Leaf & Epi \\
\hline & Burkholderia fungorum & SC121 & 99 & MH256507 & Leaf & Epi \\
\hline & Burkholderia fungorum & SC122 & 99 & MH256508 & Leaf & Epi \\
\hline & Burkholderia fungorum & SC123 & 99 & MH256509 & sheath & Endo \\
\hline & Burkholderia fungorum & SC124 & 99 & MH256510 & Leaf & Endo \\
\hline & Burkholderia fungorum & SC125 & 99 & MH256511 & Leaf & Endo \\
\hline & Burkholderia fungorum & SC126 & 99 & MH256512 & Leaf & Endo \\
\hline & Burkholderia fungorum & SC127 & 99 & MH256513 & Leaf & Endo \\
\hline & Burkholderia fungorum & SC128 & 99 & MH256514 & Leaf & Endo \\
\hline & Burkholderia fungorum & SC129 & 99 & MH256515 & Leaf & Endo \\
\hline & Burkholderia fungorum & SC130 & 99 & $\mathrm{MH} 256516$ & Leaf & Endo \\
\hline & Burkholderia fungorum & SC131 & 99 & MH256517 & Leaf & Endo \\
\hline & Burkholderia fungorum & SC132 & 99 & MH256518 & Leaf & Endo \\
\hline & Burkholderia fungorum & SC133 & 99 & MH256519 & Leaf & Epi \\
\hline
\end{tabular}




\begin{tabular}{|c|c|c|c|c|c|c|}
\hline & $\begin{array}{l}\text { Burkholderia fungorum } \\
\text { Burkholderia fungorum } \\
\text { Burkholderia fungorum } \\
\text { Burkholderia contaminans } \\
\text { Burkholderia contaminans } \\
\text { Ralstonia pseudosolanacearum } \\
\text { Ralstonia pseudosolanacearum } \\
\text { Ralstonia syzygii } \\
\text { Ralstonia pickettii } \\
\text { Ralstonia pickettii } \\
\text { Ralstonia solanacearum } \\
\text { Ralstonia solanacearum } \\
\end{array}$ & $\begin{array}{l}\text { SC134 } \\
\text { SC135 } \\
\text { SC136 } \\
\text { SC137 } \\
\text { SC138 } \\
\text { SC156 } \\
\text { SC157 } \\
\text { SC158 } \\
\text { SC159 } \\
\text { SC160 } \\
\text { SC161 } \\
\text { SC162 }\end{array}$ & $\begin{array}{l}99 \\
99 \\
99 \\
99 \\
99 \\
99 \\
99 \\
99 \\
99 \\
99 \\
99 \\
99\end{array}$ & $\begin{array}{l}\text { MH256520 } \\
\text { MH256521 } \\
\text { MH256522 } \\
\text { MH256523 } \\
\text { MH256524 } \\
\text { MH256541 } \\
\text { MH256542 } \\
\text { MH256543 } \\
\text { MH256544 } \\
\text { MH256545 } \\
\text { MH256546 } \\
\text { MH256547 }\end{array}$ & $\begin{array}{l}\text { Leaf } \\
\text { Leaf } \\
\text { Leaf } \\
\text { sheath } \\
\text { sheath } \\
\text { Leaf } \\
\text { Leaf } \\
\text { Leaf } \\
\text { sheath } \\
\text { sheath } \\
\text { Leaf } \\
\text { Leaf }\end{array}$ & $\begin{array}{l}\text { Epi } \\
\text { Epi } \\
\text { Endo } \\
\text { Endo } \\
\text { Endo } \\
\text { Endo } \\
\text { Endo } \\
\text { Endo } \\
\text { Endo } \\
\text { Endo } \\
\text { Endo } \\
\text { Endo }\end{array}$ \\
\hline $\begin{array}{r}\text { Group II } \\
\alpha-\text { Proteobacteria }\end{array}$ & $\begin{array}{l}\text { Mesorhizobium huakuii } \\
\text { Mesorhizobium huakuii } \\
\text { Mesorhizobium huakuii } \\
\text { Mesorhizobium huakuii } \\
\text { Mesorhizobium huakuii } \\
\text { Ochrobactrum ciceri } \\
\text { Ochrobactrum ciceri } \\
\text { Ochrobactrum ciceri } \\
\text { Ochrobactrum ciceri } \\
\text { Ochrobactrum ciceri } \\
\text { Ochrobactrum ciceri } \\
\text { Ochrobactrum ciceri } \\
\text { Sphingomonas pseudosanguinis }\end{array}$ & $\begin{array}{l}\text { SC139 } \\
\text { SC140 } \\
\text { SC141 } \\
\text { SC142 } \\
\text { SC143 } \\
\text { SC144 } \\
\text { SC145 } \\
\text { SC146 } \\
\text { SC147 } \\
\text { SC148 } \\
\text { SC149 } \\
\text { SC150 } \\
\text { SC167 }\end{array}$ & $\begin{array}{l}99 \\
99 \\
98 \\
98 \\
99 \\
99 \\
99 \\
99 \\
99 \\
99 \\
99 \\
99 \\
99\end{array}$ & $\begin{array}{l}\text { MH256525 } \\
\text { MH256526 } \\
\text { MH256527 } \\
\text { MH256528 } \\
\text { MH256529 } \\
\text { MH256530 } \\
\text { MH256531 } \\
\text { MH256532 } \\
\text { MH256533 } \\
\text { MH256534 } \\
\text { MH256535 } \\
\text { MH256536 } \\
\text { MH256552 }\end{array}$ & $\begin{array}{l}\text { Leaf } \\
\text { Leaf } \\
\text { Leaf } \\
\text { Leaf } \\
\text { Leaf } \\
\text { sheath } \\
\text { Leaf } \\
\text { Leaf } \\
\text { Leaf } \\
\text { Leaf } \\
\text { Leaf } \\
\text { Leaf } \\
\text { sheath }\end{array}$ & $\begin{array}{l}\text { Epi } \\
\text { Endo } \\
\text { Endo } \\
\text { Endo } \\
\text { Endo } \\
\text { Endo } \\
\text { Endo } \\
\text { Endo } \\
\text { Endo } \\
\text { Epi } \\
\text { Epi } \\
\text { Endo } \\
\text { Epi }\end{array}$ \\
\hline $\begin{array}{r}\text { GroupIII } \\
\text { Actinobacteria } \\
\text { Microbacteriaceae } \\
\text { family }\end{array}$ & $\begin{array}{l}\text { Microbacterium proteolyticum } \\
\text { Microbacterium proteolyticum } \\
\text { Microbacterium foliorum } \\
\text { Microbacterium arborescens } \\
\text { Microbacterium resistens } \\
\text { Curtobacterium flaccumfaciens } \\
\text { Curtobacterium flaccumfaciens } \\
\text { Leifsonia psychrotolerans }\end{array}$ & $\begin{array}{l}\text { SC151 } \\
\text { SC152 } \\
\text { SC153 } \\
\text { SC154 } \\
\text { SC155 } \\
\text { SC163 } \\
\text { SC164 } \\
\text { SC165 }\end{array}$ & $\begin{array}{l}97 \\
99 \\
99 \\
99 \\
99 \\
99 \\
99 \\
97\end{array}$ & $\begin{array}{l}\text { MH256537 } \\
\text { MH256538 } \\
\text { MH256539 } \\
\text { MH256553 } \\
\text { MH256540 } \\
\text { MH256548 } \\
\text { MH256549 } \\
\text { MH256550 }\end{array}$ & $\begin{array}{l}\text { Leaf } \\
\text { Leaf } \\
\text { Leaf } \\
\text { sheath } \\
\text { Leaf } \\
\text { Leaf } \\
\text { Leaf } \\
\text { Leaf }\end{array}$ & $\begin{array}{l}\text { Endo } \\
\text { Endo } \\
\text { Endo } \\
\text { Endo } \\
\text { Epi } \\
\text { Endo } \\
\text { Endo } \\
\text { Epi }\end{array}$ \\
\hline $\begin{array}{r}\text { Group IV } \\
y \text {-Proteobacteria }\end{array}$ & Xanthomonas campestris & SC166 & 98 & MH256551 & Leaf & Epi \\
\hline
\end{tabular}

${ }^{1}$ Endophytic bacteria

${ }^{2}$ Epiphytic bacteria 


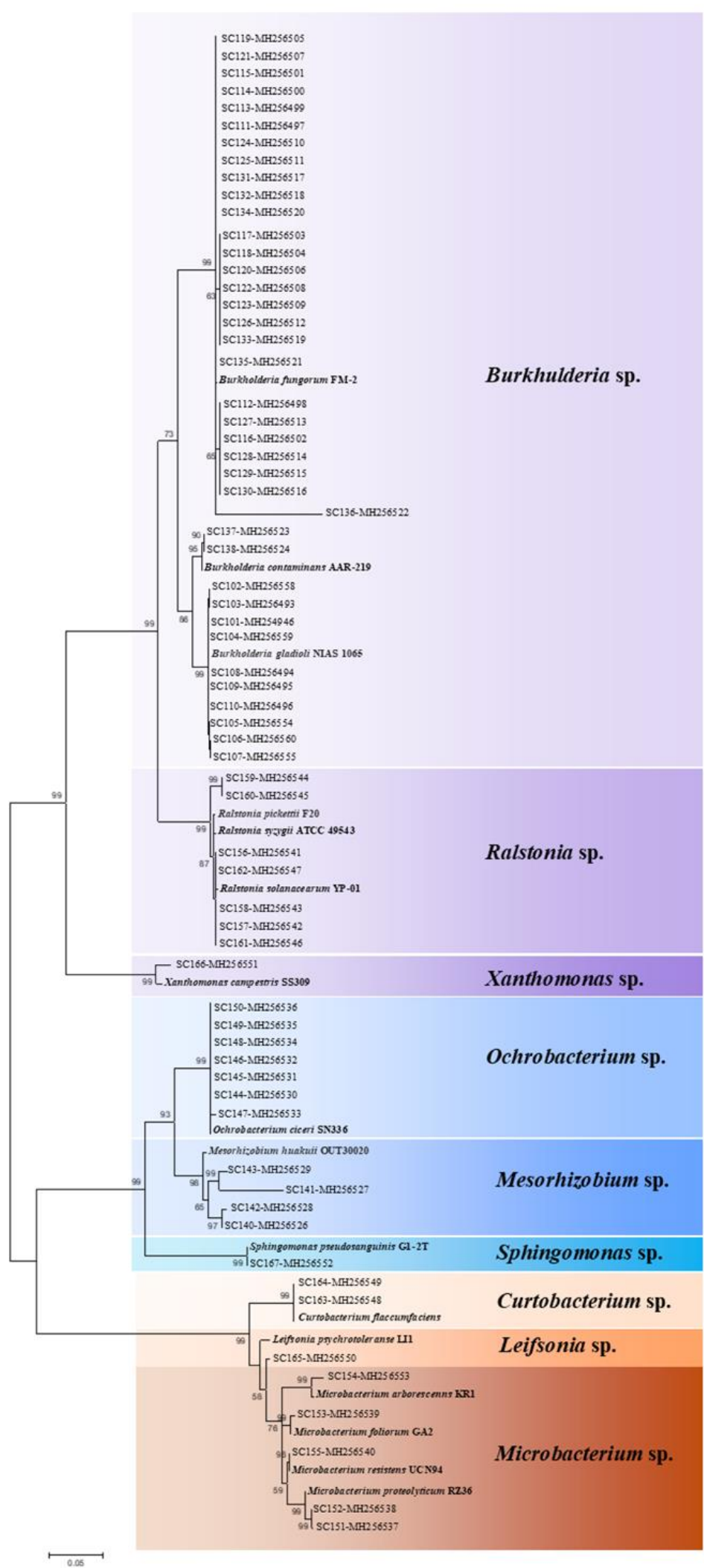

Figure 1. Neighbor joining tree of $16 S$ rRNA gene sequences from endophytic bacterial isolates from sugarcane plants. 


\section{DISCUSSION}

The bacterial strains isolated from sugarcane in Khuzestan in this study were genetically diverse and belonged to divergent phylogenetic groups of bacteria from the phyla Proteobacteria and Actinobacteria. The 16S rRNA gene sequences of the strains isolated allow their classification within the genera Burkholderia, Ralstonia, Mesorhizobium, Ochrobactrum, Sphingomonas, Xanthomonas, Curtobacterium, Leifsonia, and Microbacterium. The results of this study indicate that Burkholderia has dominated the rest of the genera and found this genus more in leaves. Previously, Mendes et al. [15] separated this genus from the roots and sugarcane stems and stated that the largest population was in the root. Burkholderia species have been isolated from various crops [16, 17], including sugarcane [18], rice [19], wine plants [20], onion [21], maize, and coffee [22-23]. The high frequency of Burkholderia species among the bacteria from sugarcane plants and their strong growth-inhibitory activity against $F$. moniliforme make these isolates potential candidates for the control of Pokkah boeng disease [15]. Previous studies have shown that strains belonging to the genus Burkholderia are effective biocontrol agents [24].

Thirteen strains belonged to the a-Proteobacteria phylum, which are in the genera Ochrobactrum, Mesorhizobium, and Sphingomonas. The Ochrobactrum strains have been isolated from various sources, mainly plant rhizospheres, clinical material and aquatic habitats [25-28]. This genus inhibited the growth of the pathogen Colletotrichum falcatum on PDA plates in vitro and reduced red rot infection in vivo [28-29]. Eight strains belonged to the Microbacteriaceae, a family that includes Gram positive bacteria with high $\mathrm{G}+\mathrm{C}$ within the phylum Actinobacteria. The strains SC151 to SC155 were related to Microbacterium sp.. This genus has been previously reported as endophytic bacteria in wheat [30], clover [31], and sorghum and soybeans [32]. The phylum also includes Leifsonia psychrotoleransan, endophytic bacteria Which was formerly detached from the mossy soil by Ganzert et al. [33]. In the present study, Curtobacterium strains were obtained from all sugarcane leaves and comprised $2.9 \%$ of total bacteria (the strains SC163 and SC164). The strains were more than $99 \%$ similar to the species $C$. flaccumfaciens. The Curtobacterium strains have been isolated as typical endophytes from several woody plants like sweet-orange, coffee, and grapevine [34-36]. Previously Araujo et al. [36] found that the endophytic bacteria $C$. flaccumfaciens has a higher density only in asymptomatic citrus plants, and hence suggested that $C$. flaccumfaciens may play a key role in citrus resistance to Citrus variegated chlorosis. Several subspecies or strains of $C$. flaccumfaciens are known as causal agents of wilt and necrotic symptoms on horticultural and ornamental plants [37]. However, C. flaccumfaciens had also been reported as a biocontrol agent for cucumber [38] and to play a role in triggering induced systemic resistance [39]. One strain was classified in the family Xanthomonadaceae within the $\mathrm{y}$-Proteobacteria. The strain SC166 was belonged to the genus Xanthomonas, with the representation strain SC166 being 98\% similar to Xanthomonas campestris. The $X$. campestris strains have been found in the endophytic populations from citrus and clover plants [31,35]. The difference in the bacterial association was attached to plant age, plant source, tissue type, time of sampling, and environment condition [40]. However, our present study clearly showed that the sampling time and plant tissue type could largely impression the difference in the endophytic and epiphytic association of sugarcane plants. The bacterial society associated with sugarcane shelters numerous genera with potential for plant growth propagation and disease control. These results show that analysis of the biodiversity is necessary to better our science on plant bacterial society as a former step to study the activities and utilization of endophytes and epiphytes in agriculture, environment protection, and biotechnology.

Acknowledgments: The present study was supported by the Department of Agronomy Sugarcane Research and Training Institute, Iran. 


\section{REFERENCES}

1. Arnold AE, Maynard Z, Gilbert GS, Coley PD, Kursar TA. Are tropical fungal endophytes hyperdiverse? Ecol Lett. 2000;3(4):267-74.

2. Inácio J, Pereira P, Carvalho DM, Fonseca A, Amaral-Collaco MT, Spencer-Martins I. Estimation and diversity of phylloplane mycobiota on selected plants in a Mediterranean-type ecosystem in Portugal. Microb Ecol. 2002;44(4):344-53.

3. Lindow SE, Brandl MT. Microbiology of the phyllosphere. Appl Environ Microbiol. 2003;69(4):187583.

4. Yadav RKP, Halley JM, Karamanoli K, Constantinidou HI, Vokou D. Bacterial populations on the leaves of Mediterranean plants: quantitative features and testing of distribution models. Environ Experiment Bot. 2004;52(1):63-77.

5. Yadav RKP, Karamanoli K, Vokou D. Bacterial colonization of the phyllosphere of Mediterranean perennial species as influenced by leaf structural and chemical features. Microb Ecol. 2005;50(2):185-96.

6. Stapleton $A E$, Simmons SJ. Plant control of phyllosphere diversity: genotype interactions with ultraviolet-B radiation. Microb Ecol.Aerial Plant Surf. 2006:223-38.

7. Bodenhausen N, Horton MW, Bergelson J. Bacterial communities associated with the leaves and the roots of Arabidopsis thaliana. PloS one. 2013;8(2): e56329.

8. Rasche F, Trondl R, Naglreiter C, Reichenauer TG, Sessitsch A. Chilling and cultivar type affect the diversity of bacterial endophytes colonizing sweet pepper (Capsicum anuum L.). Canad J Microbiol. 2006;52(11):1036-45.

9. Mukhtar I, Mushtaq S, Ali A, Khokhar I. Epiphytic and endophytic phyllosphere microflora of Cassytha filiformis L. and its hosts. Ecoprint: Int J Ecol. 2010; 17:1-8.

10. Eppo. Curtobacterium flaccumfaciens pv. flaccumfaciens. OEPP/EPPO Bulletin. 2011 41:320-328.

11. Schaad NW, Jones JB, Chun W. Laboratory Guide for the Identification of Plant Pathogenic Bacteria. 3rd ed. American Phytopathological Society (APS Press); 2001.

12. Thompson JD, Higgins DG, Gibson TJ. CLUSTAL W: improving the sensitivity of progressive multiple sequence alignment through sequence weighting, position-specific gap penalties and weight matrix choice. Nucleic Acids Res. 1994;22(22):4673-80.

13. Jukes TH, Cantor CR. Evolution of protein molecules. Mammal protein metabolism. 1964;3(21):132.

14. Tamura K, Stecher G, Peterson D, Filipski A, Kumar S. MEGA6: molecular evolutionary genetics analysis version 6.0. Mol Biol Evol. 2013;30(12):2725-9.

15. Mendes R, Pizzirani-Kleiner AA, Araujo WL, Raaijmakers JM. Diversity of cultivated endophytic bacteria from sugarcane: genetic and biochemical characterization of Burkholderia cepacia complex isolates. Appl. Environ. Microbiol., 2007. 73(22), 7259-7267.

16. Berg, G.; Krechel, A.; Ditz, M.; Sikora, R. A.; Ulrich, A.; Hallmann, J. Endophytic and ectophytic potato-associated bacterial communities differ in structure and antagonistic function against plant pathogenic fungi. FEMS Microbiol Ecol. 2005;51(2):215-29.

17. Tabacchioni S, Bevivino A, Dalmastri C, Chiarini L. Bulkholderia cepacia complex in the rhizosphere: a minireview. Annal Microbiol. 2002;52(2):103-18.

18. Oliveira AD, Urquiaga S, Döbereiner J, Baldani Jl. The effect of inoculating endophytic N 2-fixing bacteria on micropropagated sugarcane plants. Plant and Soil. 2002;242(2):205-15.

19. De Souza JT, Raaijmakers JM. Polymorphisms within the prnD and pltC genes from pyrrolnitrin and pyoluteorin-producing Pseudomonas and Burkholderia spp. FEMS Microbiol Ecol. 2003;43(1):21-34.

20. Compant S, Reiter B, Sessitsch A, Nowak J, Clément C, Barka EA. Endophytic colonization of Vitis vinifera L. by plant growth-promoting bacterium Burkholderia sp. strain PsJN. Appl Environ Microbiol. 2005;71(4):1685-93. 
21. Sessitsch A, Coenye T, Sturz AV, Vandamme P, Barka EA, Salles JF, Wang-Pruski G. Burkholderia phytofirmans sp. nov., a novel plant-associated bacterium with plant-beneficial properties. Int $\mathrm{J}$ System Evol Microbiol. 2005;55(3):1187-92.

22. Estrada P, Mavingui P, Cournoyer B, Fontaine F, Balandreau J, Caballero-Mellado J. A N2-fixing endophytic Burkholderia sp. associated with maize plants cultivated in Mexico. Canad J Microbiol. 2002;48(4):285-94.

23. Estrada-De Los Santos P, Bustillos-Cristales R, Caballero-Mellado J. Burkholderia, a genus rich in plant-associated nitrogen fixers with wide environmental and geographic distribution. Appl Environ Microbiol. 2001;67(6):2790-8.

24. Bevivino A, Dalmastri C, Tabacchioni S, Chiarini L. Efficacy of Burkholderia cepacia MCI 7 in disease suppression and growth promotion of maize. Biol Fertility Soil. 2000;31(3-4):225-31.

25. Dunne C, Crowley JJ, Moënne-Loccoz Y, Dowling DN, O'Gara F. Biological control of Pythium ultimum by Stenotrophomonas maltophilia W81 is mediated by an extracellular proteolytic activity. Microbiol. 1997;143(12):3921-31.

26. Ryan RP, Monchy S, Cardinale M, Taghavi S, Crossman L, Avison MB, Dow JM. The versatility and adaptation of bacteria from the genus Stenotrophomonas. Nat Rev Microbiol. 2009;7(7):514.

27. Imran A, Hafeez FY, Frühling A, Schumann P, Malik KA, Stackebrandt E. Ochrobactrum ciceri sp. nov., isolated from nodules of Cicer arietinum. Int J System Evol Microbiol. 2010;60(7):1548-53.

28. Hassan MN, Afghan S, Hafeez FY. Suppression of red rot caused by Colletotrichum falcatum on sugarcane plants using plant growth-promoting rhizobacteria. Biocontrol. 2010;55(4):531-42.

29. Hassan MN, Afghan S, Hafeez FY. Biological control of red rot in sugarcane by native pyoluteorin-producing Pseudomonas putida strain $\mathrm{NH}-50$ under field conditions and its potential modes of action. Pest Manage Sci. 2011;67(9):1147-54.

30. Conn VM, Franco CM. Effect of microbial inoculants on the indigenous actinobacterial endophyte population in the roots of wheat as determined by terminal restriction fragment length polymorphism. Appl Environ Microbiol. 2004;70(11):6407-13.

31. Burch G, Sarathchandra U. Activities and survival of endophytic bacteria in white clover (Trifolium repens L.). Canad J Microbiol. 2006;52(9):848-56.

32. Zinniel DK, Lambrecht P, Harris NB, Feng Z, Kuczmarski D, Higley P, Vidaver AK. Isolation and characterization of endophytic colonizing bacteria from agronomic crops and prairie plants. Appl Environ Microbiol. 2002;68(5):2198-220.

33. Ganzert L, Bajerski F, Mangelsdorf K, Lipski A, Wagner D. Leifsonia psychrotolerans sp. nov., a psychrotolerant species of the family Microbacteriaceae from Livingston Island, Antarctica. Int $\mathrm{J}$ System Evol Microbiol. 2011;61(8):1938-43.

34. Bell CR, Dickie GA, Harvey WLG, Chan JWYF. Endophytic bacteria in grapevine. Canad J Microbiol. 1995;41(1):46-53.

35. Araújo WL, Marcon J, Maccheroni W, van Elsas JD, van Vuurde JW, Azevedo JL. Diversity of endophytic bacterial populations and their interaction with Xylella fastidiosa in citrus plants. Appl Environ Microbiol. 2002;68(10):4906-14.

36. Vega FE, Pava-Ripoll M, Posada F, Buyer JS. Endophytic bacteria in Coffea arabica L. J Basic Microbiol. 2005;45(5):371-80.

37. Vidaver AK. The plant pathogenic corynebacteria. Annual Rev Microbiol. 1982;36(1):495-517.

38. Raupach GS, Kloepper JW. Biocontrol of cucumber diseases in the field by plant growth-promoting rhizobacteria with and without methyl bromide fumigation. Plant Disease. 2000;84(10):1073-5.

39. Raupach GS, Kloepper J. W. Mixtures of plant growth-promoting rhizobacteria enhance biological control of multiple cucumber pathogens. Phytopathol. 1998;88(11):1158-64.

40. Kobayashi DY, Palumbo JD. Bacterial endophytes and their effects on plants and uses in agriculture. Microb Endophytes. 2000; 19:199-233. 
(C) $(5)$
under the terms and conditions of the Creative Commons Attribution (CC
BY NC) license (https://creativecommons.org/licenses/by-nc/4.0/). 